\title{
An early Brunhes (<0.78 Ma) age for the Lower Paleolithic tool-bearing Kozarnika cave sediments, Bulgaria
}

\author{
Giovanni Muttoni a, b, *, Nikolas Sirakov ${ }^{c}$, Jean-Luc Guadelli ${ }^{d}$, Dennis V. Kent ${ }^{\text {e, }}$, \\ Giancarlo Scardia $^{g}$, Edoardo Monesi ${ }^{\mathrm{a}, \mathrm{b}}$, Andrea Zerboni ${ }^{\mathrm{a}, \mathrm{b}}$, Enzo Ferrara ${ }^{\mathrm{h}}$ \\ a Dipartimento di Scienze della Terra 'Ardito Desio', Università degli Studi di Milano, Via Mangiagalli 34, I-20133 Milano, Italy \\ ${ }^{\mathrm{b}}$ ALP - Alpine Laboratory of Paleomagnetism, Via Luigi Massa, 6, I-12016 Peveragno, Italy \\ ${ }^{\mathrm{c}}$ National Institute of Archaeology and Museum of Bulgarian Academy of Sciences, 2, Saborna Street, 1000 Sofia, Bulgaria \\ d PACEA-UMR5199 CNRS, Université de Bordeaux, Allée Geoffroy Saint-Hilaire, Bâtiment B18, CS50023, 33615 Pessac Cedex, France \\ e Earth and Planetary Sciences, Rutgers University, Piscataway, NJ 08854, USA \\ ${ }^{\mathrm{f}}$ Lamont-Doherty Earth Observatory of Columbia University, Palisades, NY 10964, USA \\ ${ }^{\mathrm{g}}$ Universidade Estadual Paulista (UNESP), Instituto de Geociências e Ciências Exatas, Rio Claro, SP 13506-900, Brazil \\ ${ }^{\mathrm{h}}$ Istituto Nazionale di Ricerca Metrologica, Nanosciences and Materials Division, INRIM, Torino 10135, Italy
}

\section{A R T I C L E I N F O}

\section{Article history:}

Received 13 September 2017

Accepted 25 October 2017

\section{Keywords:}

Kozarnika

Bulgaria

Pleistocene

Lithic tools

Magnetostratigraphy

Brunhes

Matuyama

\begin{abstract}
A B S T R A C T
We present a new sedimentological profile and a magnetostratigraphy of the tool-bearing Kozarnika cave sediments from Bulgaria. Modal analysis of cave infilling sedimentary texture indicates that the toolbearing layers contain a sizable fraction of sediment interpreted as loess. We also find evidence for a relatively thick and well defined normal magnetic polarity in the upper-middle part of the section interpreted as a record of the Brunhes Chron, followed down-section by reverse polarity directions interpreted as a record of the Matuyama Chron. The lowermost levels with Lower Paleolithic tools (Layers $13 \mathrm{a}-\mathrm{c}$ ) lie in the early Brunhes at a nominal maximum age of $\sim 0.75 \mathrm{Ma}$, while the Brunhes -Matuyama boundary ( $0.78 \mathrm{Ma})$ falls in Layer 13 Lower immediately below. This finding represents a conspicuous revision of previous age estimates for the same tool-bearing layers.
\end{abstract}

(c) 2017 Elsevier Ltd. All rights reserved.

\section{Introduction}

The Kozarnika cave (Sirakov et al., 2010 and references therein), located in northwestern Bulgaria (Fig. 1) at the margin of the Danube loess basin (Haase et al., 2007), is the repository of a $9 \mathrm{~m}$ thick stratigraphic succession containing lithological units (Ferrier et al., 2009; Sirakov et al., 2010) labeled from Layers 3-4 at the top to Layer 14 at the bottom (Fig. 2). This sequence hosts various archaeological complexes spanning from the Neolithic (and younger) at the top followed downsection by a blade industry termed Kozarnikian, then Middle Paleolithic and Lower Paleolithic industries (Fig. 2) (details in Guadelli et al., 2005; Sirakov et al., 2010).

The upper Layers 3-10b yielded radiocarbon and optically

\footnotetext{
* Corresponding author. Dipartimento di Scienze della Terra 'Ardito Desio', Università degli Studi di Milano, Via Mangiagalli 34, I-20133 Milano, Italy.

E-mail address: giovanni.muttoni1@unimi.it (G. Muttoni).
}

stimulated luminescence (OSL) ages broadly spanning from $13.2 \mathrm{ka}$ to $183 \mathrm{ka}$ ( $\mathrm{ka}=$ kiloannum = one thousand years ago) (details in Guadelli et al., 2005; Tillier et al., 2017; see also below). Large mammal biostratigraphy seems to indicate that Layers $11 \mathrm{~b}$ to $13 \mathrm{c}$ should belong to Mammal Neogene/Quaternary (MNQ) zones 19 to 17 with an attributed age of $\sim 1.4-1.6 \mathrm{Ma}$ ( $\mathrm{Ma}=$ megaannum $=$ one million years ago) (Guadelli et al., 2005; Sirakov et al., 2010; but see Popov and Marinska, 2007 for an alternative interpretation). These mammal age assessments are however potentially marred by the lack of continuity of the Kozarnika sequence, which seems to consist of an intermittent succession of sedimentary episodes and phases of human occupation (new studies are underway to contribute resolving these uncertainties in key Layers 10c-11c).

A preliminary magnetostratigraphic investigation of the cave sediments (Sirakov et al., 2010) indicated that sediments down to the middle part of Layer 11b are characterized by normal polarity magnetization interpreted as a record of the Brunhes Chron (base at $0.78 \mathrm{Ma}$; time scale of Lourens et al., 2004). Low magnetic inclination values in the lower part of Layer 11b were tentatively 


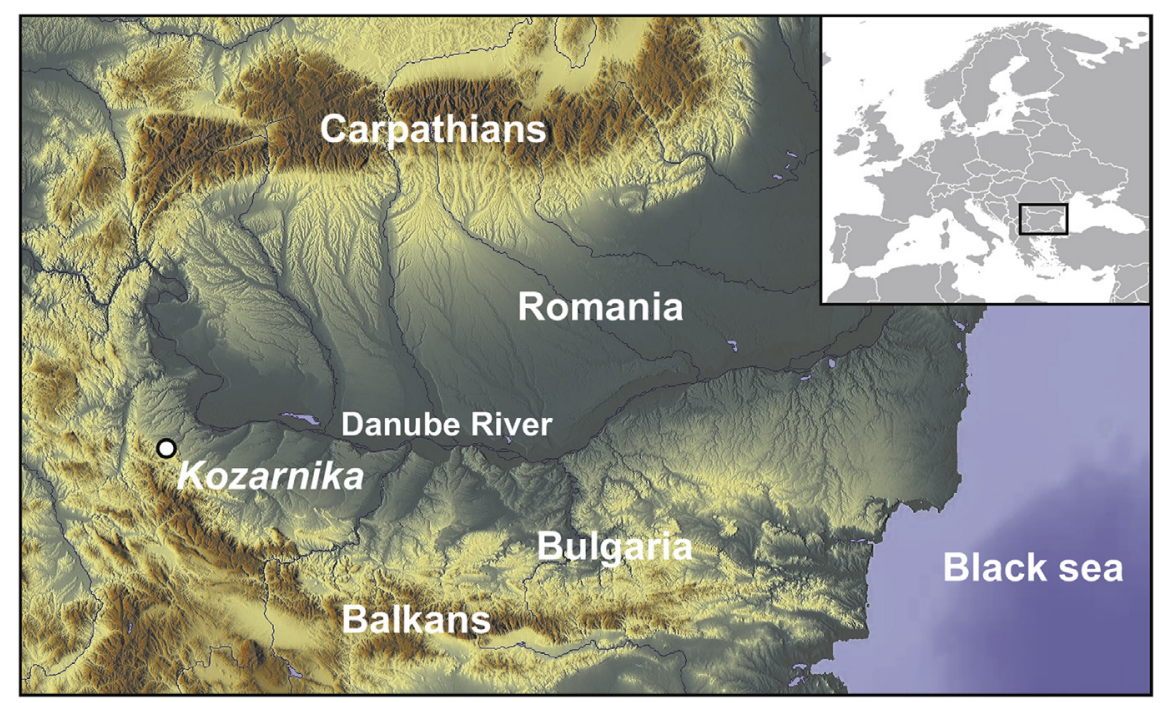

Fig. 1. Map of northwestern Bulgaria with location of the Kozarnika cave ( $43^{\circ} 39^{\prime} \mathrm{N}, 22^{\circ} 44^{\prime} \mathrm{E}$ ).

interpreted as indicating transition to reverse polarity of the Matuyama Chron, but problems of consolidation of blocks did not allow to retrieve a continuous paleomagnetic signal (Sirakov et al., 2010). According to these preliminary data (Sirakov et al., 2010), the lower archaeological levels with lithic tools would predate the Brunhes-Matuyama boundary (0.78 Ma).

Encouraged by this earlier attempt, here we report a thorough magnetostratigraphic study of the cave sediments from Layer 5 to Layer 14 coupled with a novel interpretation of the genesis of cave sediments. These results will be used to assess the stratigraphic continuity of the Kozarnika cave sequence and provide an age assessment for the lowermost levels bearing Lower Paleolithic tools.

\section{Geological setting}

\subsection{Cave stratigraphy and sedimentology}

The Kozarnika cave opens to the south at an altitude of $481 \mathrm{~m}$ on a northern hillside of a tributary valley of the Skomlia River, at about $85 \mathrm{~m}$ above the valley floor (Sirakov et al., 2010). The Skomlia valley is about $185 \mathrm{~m}$ deep and cuts through a Jurassic sequence comprised of Early Jurassic red conglomerates, Middle Jurassic yellow limestones and Late Jurassic grey limestones that host the cave (Ferrier et al., 2009). The stratigraphy of the Pleistocene cave infilling, updated after Sirakov et al. (2010), is comprised of the following set of main layers described from top to bottom (Fig. 2; see also Ferrier et al., 2009; Sirakov et al., 2010):

- Layers 3a to 4 constitute the uppermost part of the sequence and have not been sampled for magnetostratigraphy. They are altogether 1-1.4 m-thick and composed of calcareous clasts (coming from the cave walls and ceiling) in a light brown to whitish silty matrix. These layers contain archaeological levels IVb-OI attributed to middle and recent stages of the Kozarnikien, which is a local blade industry containing backed pieces. Calibrated radiocarbon ages were obtained from uppermost Layers 3a and 3b spanning from 13.2 to 24.5 ka (Guadelli et al., 2005) (Fig. 2).

- Layers 5a to $10 \mathrm{c}$ are altogether about 1.2-1.5 m-thick. The upper part of this sequence (Layers $5 a$ to $10 a$ ), is characterized by yellowish brown silts embedding calcareous clasts and blocks resulting from the fragmentation of the cave walls and ceiling. Underlying Layers $10 \mathrm{~b}$ and $10 \mathrm{c}$ consist of loose dark-brown loamy sand containing gravels and calcareous pebbles showing variable degrees of weathering. In this sequence, Layers 5a-c yielded archaeological levels V-VII attributed to the early stages of the Kozarnikien, and Layer $5 b$ yielded a calibrated radiocarbon age of $31.2 \mathrm{ka}$ (Sirakov et al., 2010) (Fig. 2). Layer 6/7 includes archaeological level VIII, which corresponds to an industry regarded as characteristic of the Middle Paleolithic and the initial Late Paleolithic; it also yielded uncalibrated radiocarbon ages ranging from 42.7 to $43.6 \mathrm{ka}$ (Sirakov et al., 2010) (Fig. 2). Layers 9a to 10a contain archaeological levels IX-XIII attributed to the Middle Paleolithic (Mousterian) while Layers $10 \mathrm{~b}$ and $10 \mathrm{c}$ contain the lower end of the Mousterian sequence. Layer 10b was recently dated with optically stimulated luminescence (OSL) from 128 to $183 \mathrm{ka}$ (Tillier et al., 2017) (Fig. 2).

- Layers 11a to $13 \mathrm{c}$ have a total thickness of about $2.5 \mathrm{~m}$ and are composed of rather compact yellowish brown loamy sediments, blotched with dark manganese-bearing nodules and more or less rich in rock blocks and pebbles (limestone blocks, flint pebbles from the cave walls, and more rarely rounded pebbles of quartz) with high degrees of alteration. These layers contain Lower Paleolithic core-and-flake, non-Acheulian industries.

- Layers 13 Lower to 14 represent the section base and are characterized by abundant limestone boulders with occasional yellowish brown, laminated sandy matrix in between. Archaeological artifacts have thus far not been recovered from these layers.

\subsection{Grain size analysis of cave sediments}

Grain size analysis was performed on Layers 9-14 to elucidate the origin of the cave sediments (Gale and Hoare, 1991). A total of 14 samples, ranging in weight from 25 to $40 \mathrm{~g}$, were treated with $10 \mathrm{ml}$ of $30 \% \mathrm{H}_{2} \mathrm{O}_{2}$ in order to remove any organic matter content. This treatment was repeated twice. After drying in an oven at $50{ }^{\circ} \mathrm{C}$, samples were gently disaggregated in an agate mortar and sieved at 1000 and $500 \mu \mathrm{m}$. Samples were weighted after each step. The $<500 \mu \mathrm{m}$ fraction was then dispersed in $0.05 \%$ sodium metaphosphate solution, disaggregated in an ultrasonic bath for $15 \mathrm{~s}$, and then passed through a Malvern Laser Particle Size Analyser 


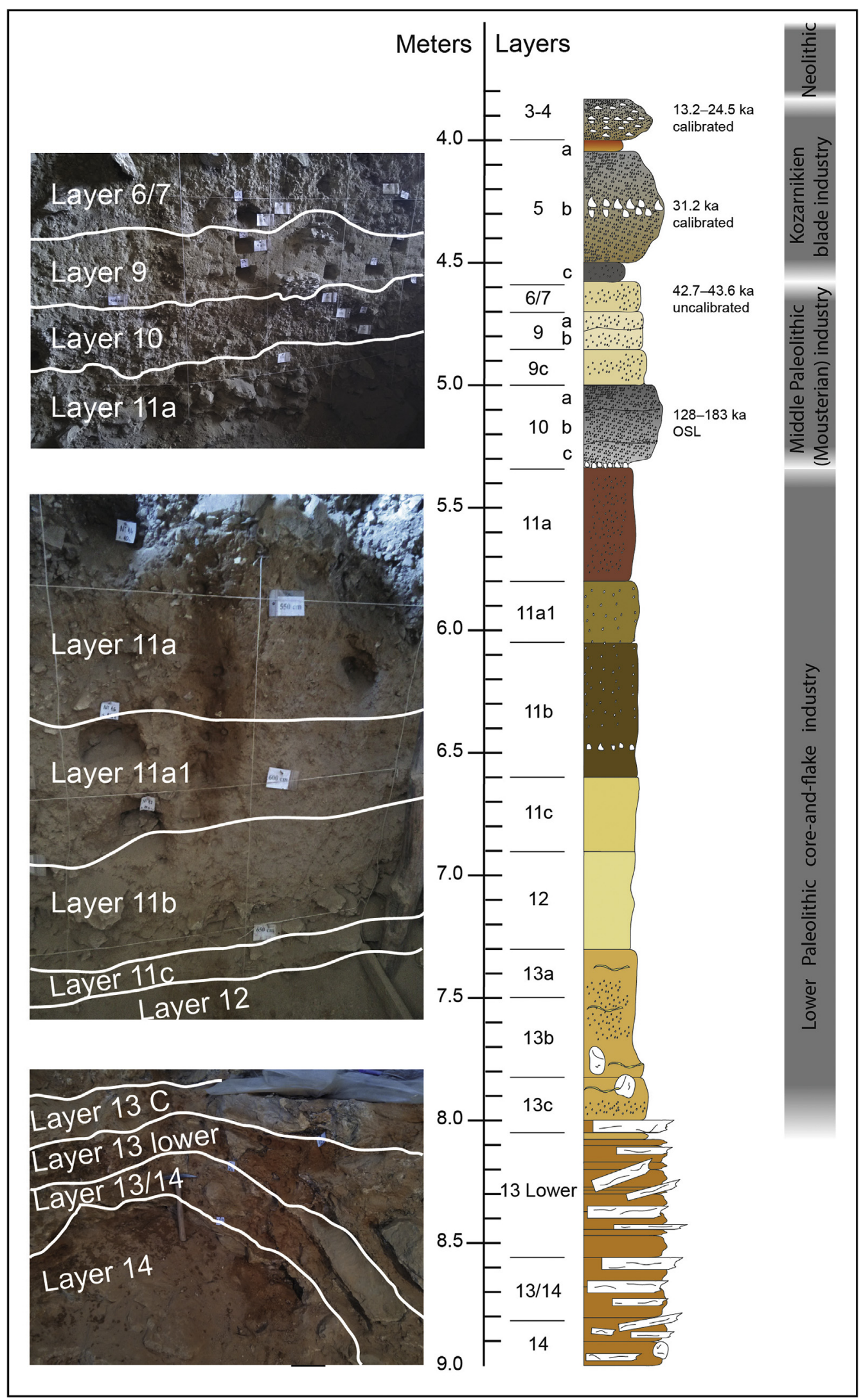

Fig. 2. Lithologic log of the studied Kozarnika cave profile (updated after Sirakov et al., 2010) with photographs of the main sampled layers. Key calibrated and uncalibrated radiocarbon ages from Layers 3 to 6/7 (Guadelli et al., 2005) and the recent OSL age from Layer 10b (Tillier et al., 2017) are reported (in ka = kiloannum) together with the main lithic industries retrieved throughout the sequence (Sirakov et al., 2010). 
(mod. Mastersizer 2000).

Curves of grain size distribution are reported in Fig. 3 and described from top to bottom of the cave section.

- Samples from upper Layers 9a-b to 10c display a bimodal distribution of particles: a broad silt mode and high coarse-grained sand ( $\geq 1000 \mu \mathrm{m}$ ) content. The clay content is high in Layers 9a-b and progressively decreases down-section, i.e., the silt mode becomes progressively narrower.

- Grain size distributions of Layers $11 \mathrm{a}$ to $13 \mathrm{~b}$ are very similar and moderately sorted. They present a well-defined silt mode centered at 20-60 $\mu \mathrm{m}$ and high coarse-grained sand $(\geq 1000 \mu \mathrm{m})$ content. A small peak is also present at $120-140 \mu \mathrm{m}$ and related to fine-to medium-grained sand, while the clay content is always very low.

- The sample from the lowermost Layer 14 is poorly sorted: it displays a skewed distribution with a long silt tail and a sand mode centered at $100-200 \mu \mathrm{m}$ as well as high coarse-grained sand $(\geq 1000 \mu \mathrm{m})$ content.

Samples from the upper Layers 9a-b to 10c, characterized by poor sorting and a broad silt mode, are tentatively interpreted as mainly colluvial loess (Krumbein and Sloss, 1963) variably mixed with coarse-grained sediments derived from the disruption of the cave walls and ceiling (see section 2.3). Ferrier et al. (2009) reported the occurrence of lenses of sand and gravel with openwork texture that supports an overall reworking by water. From these analyses and additional field observations, we consider this facies, termed 'mainly colluvial loess \& rock fragments' in Fig. 3, as extending altogether from Layer 3-4 to Layer 10c.

Samples from underlying Layers 11 a to 13 b display a welldefined and persistent silt mode (Fig. 3), interpreted as loess wind-blown into the cave (Pye, 1987, 1995; Coudé-Gaussen, 1990; Assallay et al., 1998), associated with coarse-grained sediments possibly derived from the cryogenic dismantling of the cave walls and ceiling or other endokarstic processes described by Ferrier et al. (2009). A similar bimodal grain size distribution with a dominant loess mode has been found in cave entrances and rock shelters at the margin of the Po Plain Loess Basin of northern Italy (Cremaschi, 1987; Castiglioni et al., 1990; Ferraris et al., 1990; Zerboni et al., 2015). We consider this facies, termed 'mainly cave loess \& rock fragments' in Fig. 3, as extending altogether from Layer 11a to Layer 13c.

Finally, the grain size distribution curve of basal Layer 14 suggests an alluvial origin of the sand-dominated (i.e., non-loess) sediments; moreover, at the macro-scale, Layer 14 presents laminated structure typical of water transport, in substantial agreement with Ferrier et al. (2009). We consider this facies, termed 'alluvial sand' in Fig. 3, as extending altogether from Layer 13 Lower to Layer 14.

\subsection{Scanning Electron Microscope analysis of cave sediments}

Representative samples from Layers 9, 11a-c, and 14 were selected for Scanning Electron Microscope (SEM) analysis. The $<63 \mu \mathrm{m}$ and $63-250 \mu \mathrm{m}$ fractions of 5 samples were separated by wet sieving for observation of their surface texture (Le Ribault, 1977; Martignier et al., 2013) with a Cambridge 360 SEM equipped with an energy dispersive X-ray analysis (EDS Link Isis 200 with an accelerating voltage of $20 \mathrm{kV}$, filament intensity $1.70 \mathrm{~A}$, and probe intensity of $280 \mathrm{pA}$ ) after carbon-coating.

The observed grains are rounded, sub-rounded, and subangular. Chemical composition confirms the occurrence of carbonate grains, more common in samples from colluvial Layer 9 and alluvial Layer 14, and silicate grains (quartz and subordinate igneous and

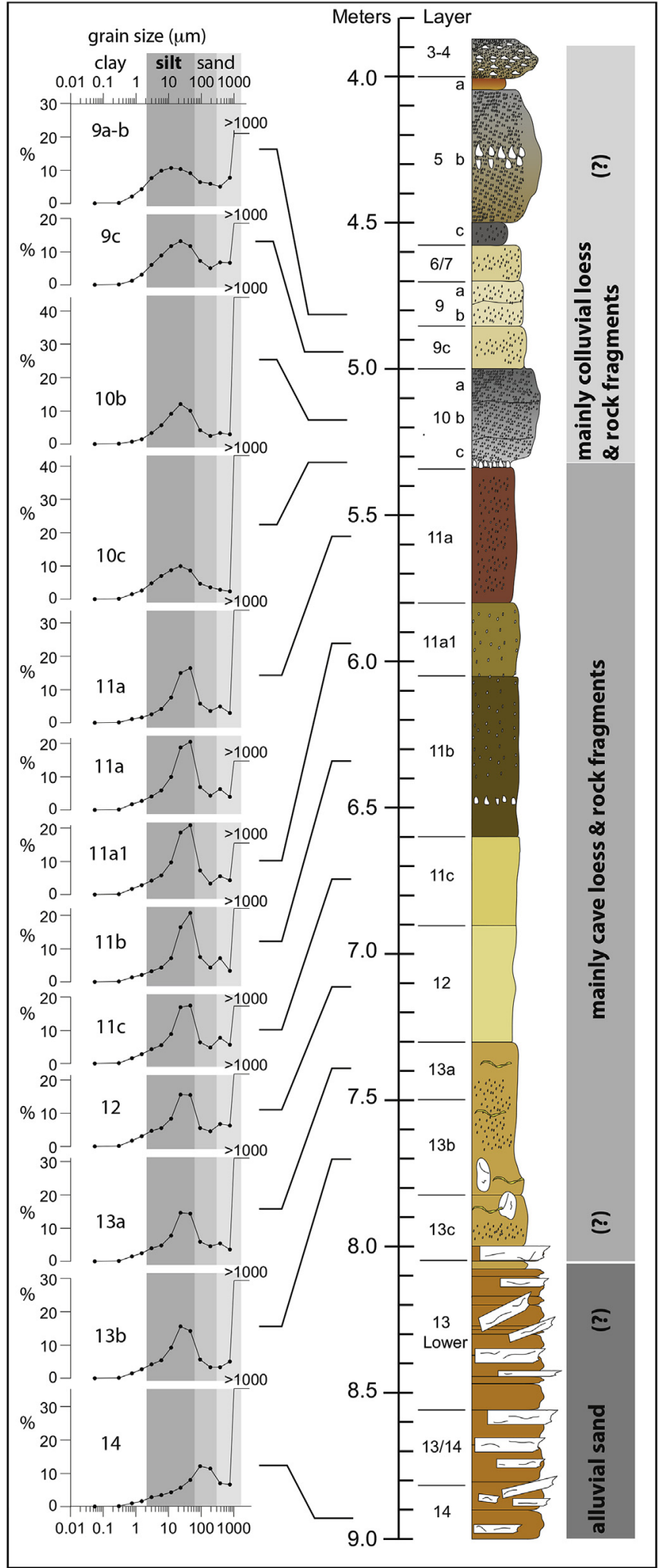

Fig. 3. Results of laser granulometry of the Kozarnika cave sediments showing a main silt mode attributed to loess in samples from Layers from 11a to 13b while overlying Layers 9a-b to $10 \mathrm{c}$ are interpreted as colluvial loess and the lowermost Layer 14 as fluvial (alluvial) sediments. 

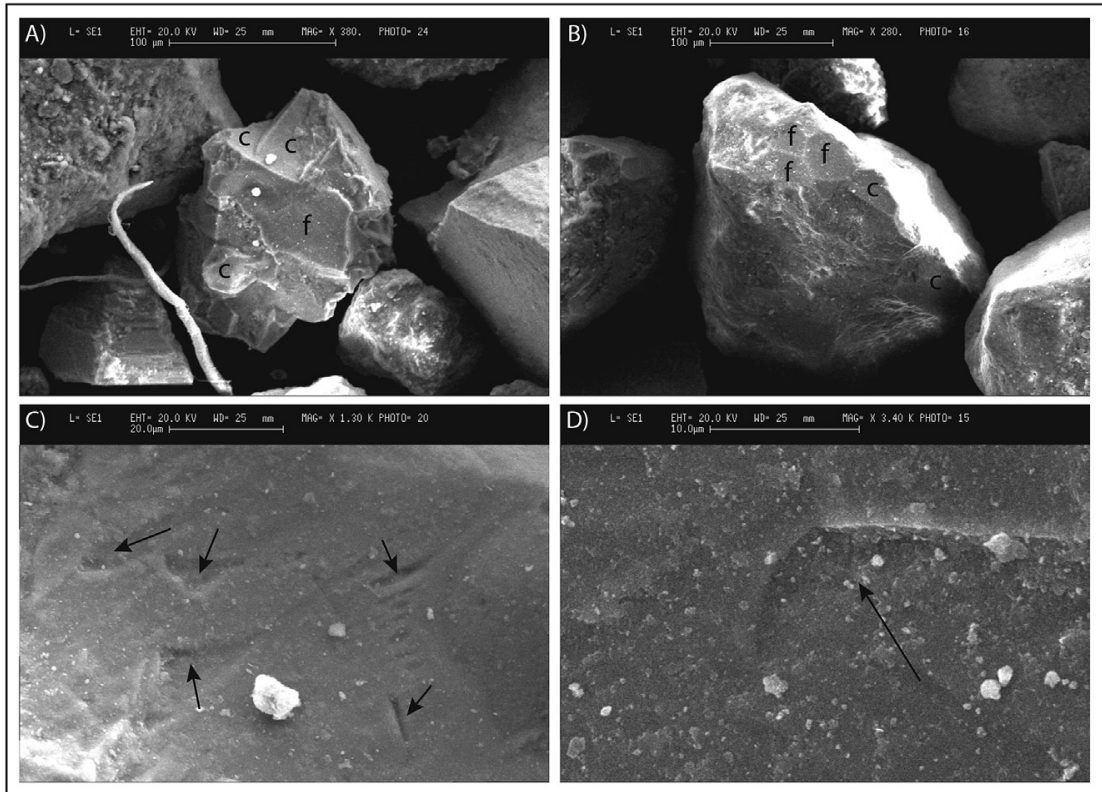

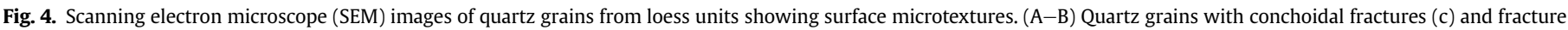
faces (f) (sample from Layer 11a); (C-D) wind transportation V-shaped percussion marks on subangular grains (arrows) (sample from Layer 11c).

metamorphic grains), more common in samples from loessdominated Layer 11a-c. In loess samples, quartz grains show many V-shaped percussion marks and impact features (Fig. 4), which are interpreted as the effect of wind transportation (Martignier et al., 2013; Pavelić et al., 2016).

EDS analysis on the bulk sediment highlighted different elemental concentrations in the samples from colluvial Layer 9 and alluvial Layer 14 (mean values of $\mathrm{Si}=17 \%, \mathrm{Ca}=43 \%, \mathrm{Al}=4 \%$, $\mathrm{Fe}=2 \%$ ) relative to the samples from eolian Layer $11 \mathrm{a}-\mathrm{c}$ (mean values of $\mathrm{Si}=50 \%, \mathrm{Ca}=21 \%, \mathrm{Al}=4 \%, \mathrm{Fe}=2 \%$; this could be interpreted as the effect of a dominant igneous and metamorphic petrography in the loess units (compatible with an allochthonous wind input) and a dominant carbonatic petrography in the alluvial units, reflecting an autochthonous origin of grains.

\section{Paleomagnetism}

\subsection{Methods}

Results from a previous paleomagnetic sampling were hampered by the unconsolidated nature of the sediments (Sirakov et al., 2010). We avoided this issue by carefully inserting $\sim 5 \mathrm{~cm}^{3}$ plastic cylinders into oriented sediment walls, obtaining a total of 173 specimens for paleomagnetic analyses from Layer 6/7 at the top to Layer 14 at the base (Fig. 5). The initial magnetic susceptibility was measured on all weighed samples at room temperature with a KLY-2 Kappabridge. A sub-set of 10 samples was subjected to rock magnetic analyses by means of back-field isothermal remanent magnetization (IRM) acquisition imparted at $-2.5 \mathrm{~T}$ along the horizontal axis in one direction $(-z)$ and then progressively increasing from $+0.025 \mathrm{~T}$ up to $+2.5 \mathrm{~T}$ in the opposite direction $(+\mathrm{z})$ (Fig. 6A, samples KZ94 and KZ52; Fig. 6B). Hysteresis analyses were conducted on 6 selected rock chips (mass 40-120 mg) using a Lake Shore 7410 Vibrating Sample Magnetometer (VSM) with maximum applied fields $H_{\max }= \pm 1 \mathrm{~T}$ (Fig. 7A). Hysteresis measurements were repeated after thermal treatment applied directly to the samples within the VSM chamber by means of a thermoresistance furnace operating in Argon atmosphere. The same apparatus was used to obtain thermomagnetic curves up to $700{ }^{\circ} \mathrm{C}$ (applied field $\mathrm{H}=200 \mathrm{mT}$ ). The thermomagnetic curves, showing magnetic moment $(\mathrm{M})$ variations as a function of temperature $(\mathrm{T})$, offer general information about the magnetic mineralogy, thermal stability, and grain size of the magnetic carriers (Fig. 7B).

To delineate the magnetostratigraphy, a complete set of samples was subjected to progressive alternating field (AF) demagnetization up to $80 \mathrm{mT}$. The natural remanent magnetization (NRM) was measured after each demagnetization step with a 2G Enterprises DC-SQUID cryogenic magnetometer located in a shielded room. Standard least-square analysis was used to calculate magnetic component directions from vector end-point demagnetization diagrams (Fig. 8), and standard Fisher statistical analysis was used to analyze the mean component directions.

\subsection{Results}

The magnetic susceptibility fluctuates around a mean value of $\sim 20^{*} 10^{-8} \mathrm{~m}^{3} / \mathrm{kg}$ throughout most of the section (with one isolated anomalously high value at $6.48 \mathrm{~m}$ ), while the section base is characterized by higher values of $\sim 40-60^{*} 10^{-8} \mathrm{~m}^{3} / \mathrm{kg}$ (Fig. 5A). The intensity of the NRM is comprised between $20^{*} 10^{-7} \mathrm{Am}^{2} / \mathrm{kg}$ and $120^{*} 10^{-7} \mathrm{Am}^{2} / \mathrm{kg}$ (punctuated by an isolated anomalously high value again at $6.48 \mathrm{~m}$ ) (Fig. 5B). During IRM acquisition experiments, $\mathrm{a}-2.5 \mathrm{~T}$ field imparted along the $-\mathrm{z}$ axis produced a parallel IRM, and subsequent fields imparted along the $+z$ axis from $+0.025 \mathrm{~T}$ up to $+2.5 \mathrm{~T}$ generated a progressively increasing antiparallel IRM aligned along the $+\mathrm{z}$ axis (Fig. 6A, samples KZ94 and KZ52). Only sample KA10 (at $6.48 \mathrm{~m}$ ) was highly anisotropic whereby the IRM generated by the $-2.5 \mathrm{~T}$ field along the $-\mathrm{z}$ axis was found to lie at high angle relative to the $-z$ axis, and subsequent fields along the $+\mathrm{Z}$ axis produced IRMs again oriented at high angles relative to the $+\mathrm{z}$ axis (Fig. 6A, sample KA10). In any case, IRM acquisition curves reveal the presence of a dominant low to moderate coercivity ferromagnetic mineral that tends to saturate in fields of only $0.06 \mathrm{~T}(60 \mathrm{mT})$ variably associated with a higher coercivity mineral that shows no tendency to saturate up to $2.5 \mathrm{~T}$ fields (Fig. 6B). The proportion of soft/hard minerals, isolated from 


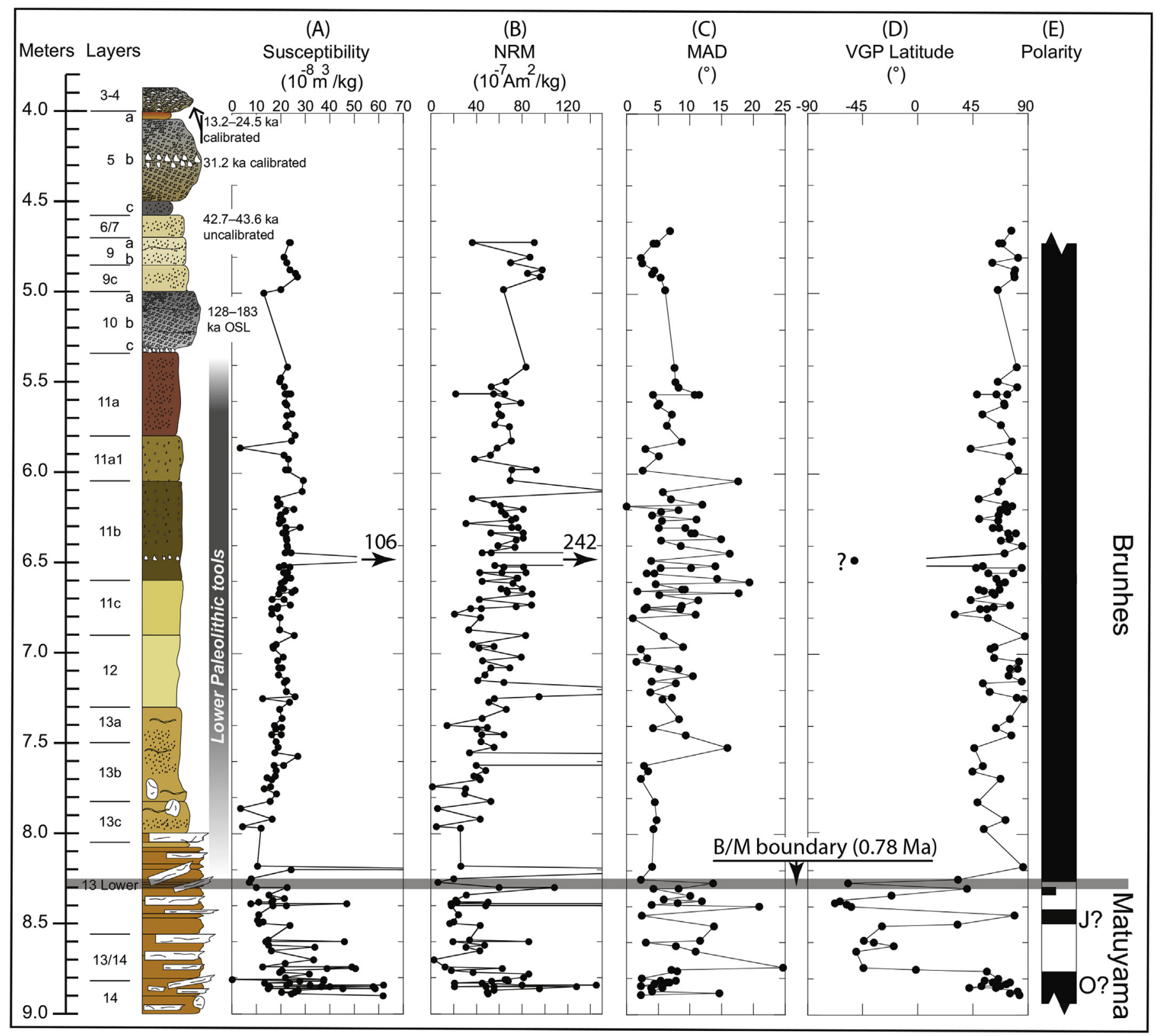

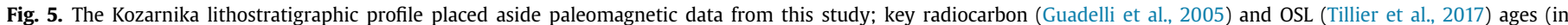

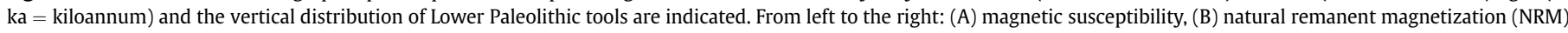

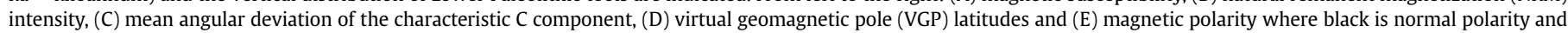

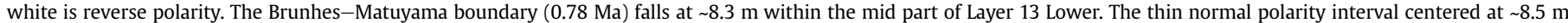

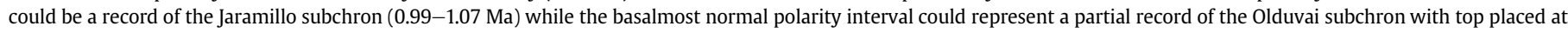
$1.78 \mathrm{Ma}$. M is Matuyama Chron. J? = Jaramillo (uncertain), $\mathrm{O}$ ? = Olduvai (uncertain).

the IRM acquisition curves following Kruiver et al. (2001), varies throughout the section whereby the hard coercivity fraction is confined to $5-10 \%$ of the total IRM from the the top of the section down to Layer $13 \mathrm{~b}$, and then increases to values of up to $20 \%$ in Layers 13 Lower and Layer 13/14 (Fig. 6C).

Hysteresis loops obtained before thermal treatment show the ubiquitous presence of a soft magnetic phase with very low coercive field $\left(\mathrm{H}_{\mathrm{c}} \sim 10 \mathrm{mT}\right)$ associated with a prevalent paramagnetic phase (Fig. 7A). After thermal treatment, magnetization and coercive force of the samples increase drastically, resulting in more clearly defined hysteresis loops. As well, magnetic susceptibility values of samples before thermal treatment are about $10-40^{*} 10^{-8} \mathrm{~m}^{3} / \mathrm{kg}$, and increase more than ten times after heating treatment. The heating branches of the thermomagnetic experiments show the presence of a Curie temperature of about $580{ }^{\circ} \mathrm{C}$ (Fig. 7B) indicative of magnetite (Dunlop and Özdemir, 1997), in agreement with the results obtained from the IRM experiments. The cooling branches show much higher magnetizations (Fig. 7B) probably due to the growth of iron oxides from paramagnetic precursors during heating. No evidence is provided through hysteresis or thermomagnetic experiments of the harder magnetic phase (hematite and/or goethite) revealed by the IRM experiments.

Vector end-point demagnetization diagrams show the presence of soft components of the remanent magnetization termed $A$ that are easily removed between $0 \mathrm{mT}$ and $10-20 \mathrm{mT}$ (Fig. 8). These A components are oriented downward (positive inclinations) with 


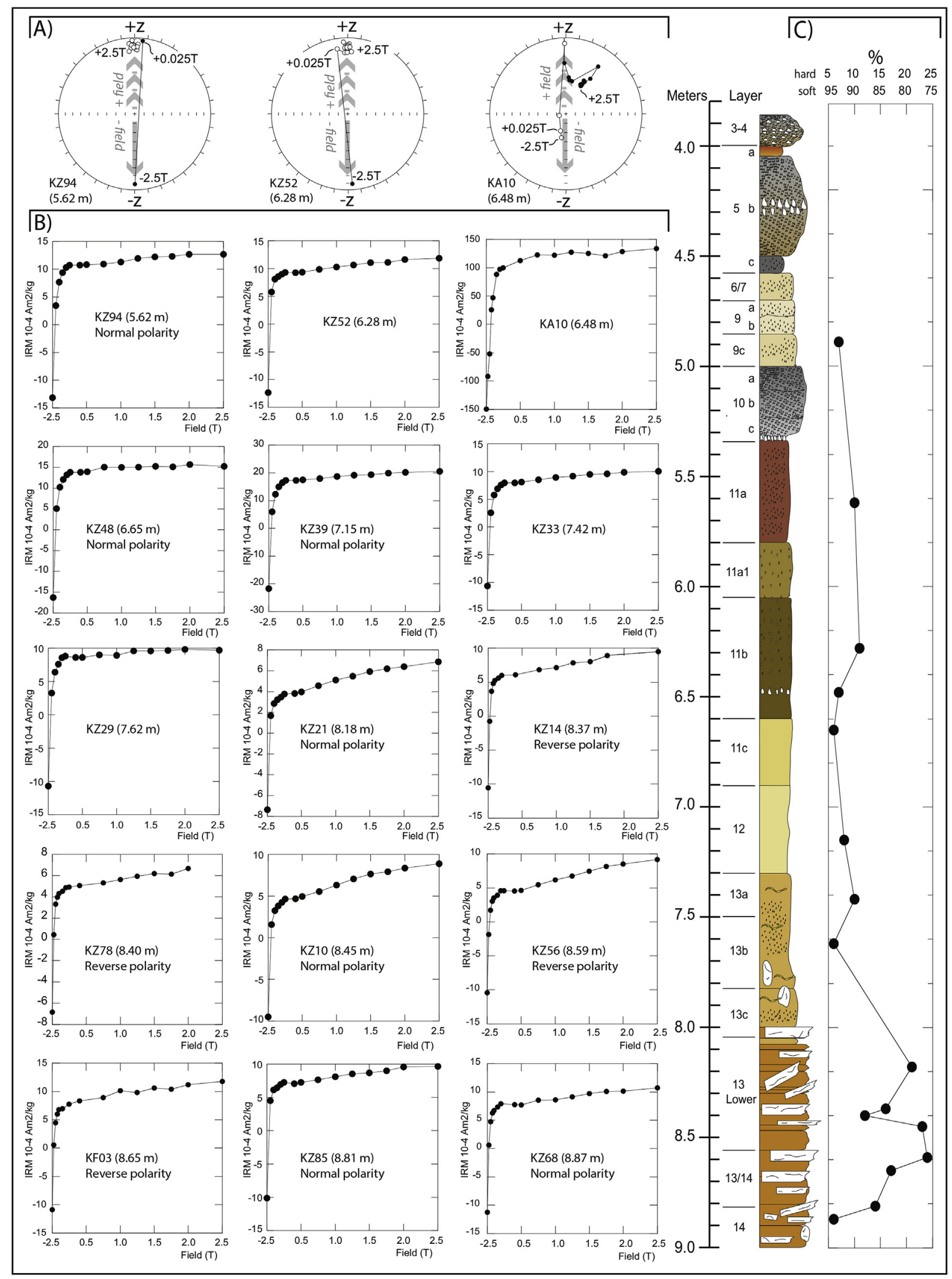

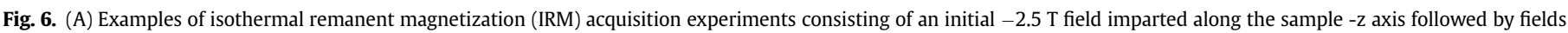

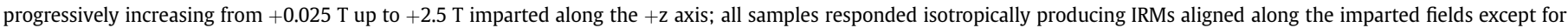

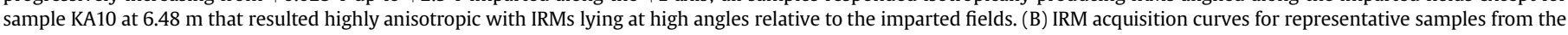

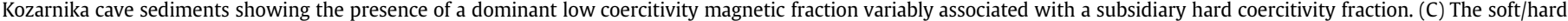
coercivity ratios of samples reveal that he hard coercivity fraction is higher (up to $20 \%$ of the total IRM) in Layers 13 Lower and Layer $13 / 14$. 


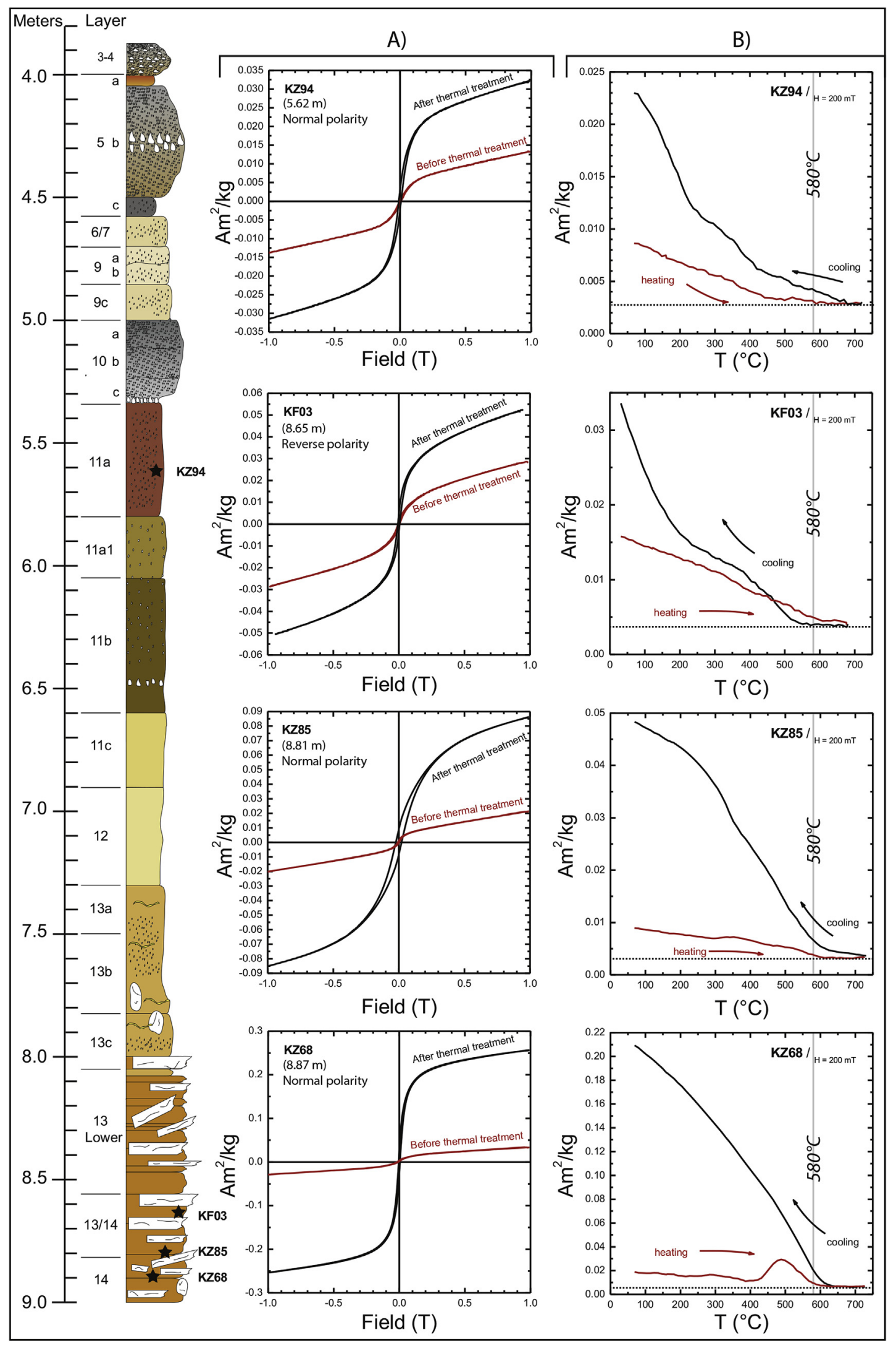

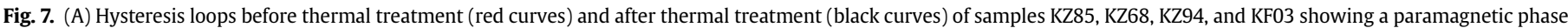

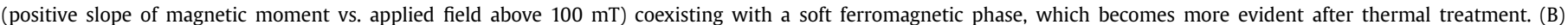

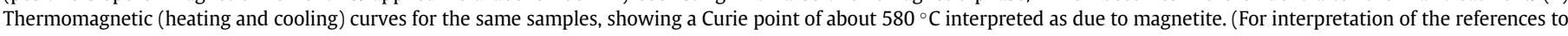
colour in this figure legend, the reader is referred to the web version of this article.) 


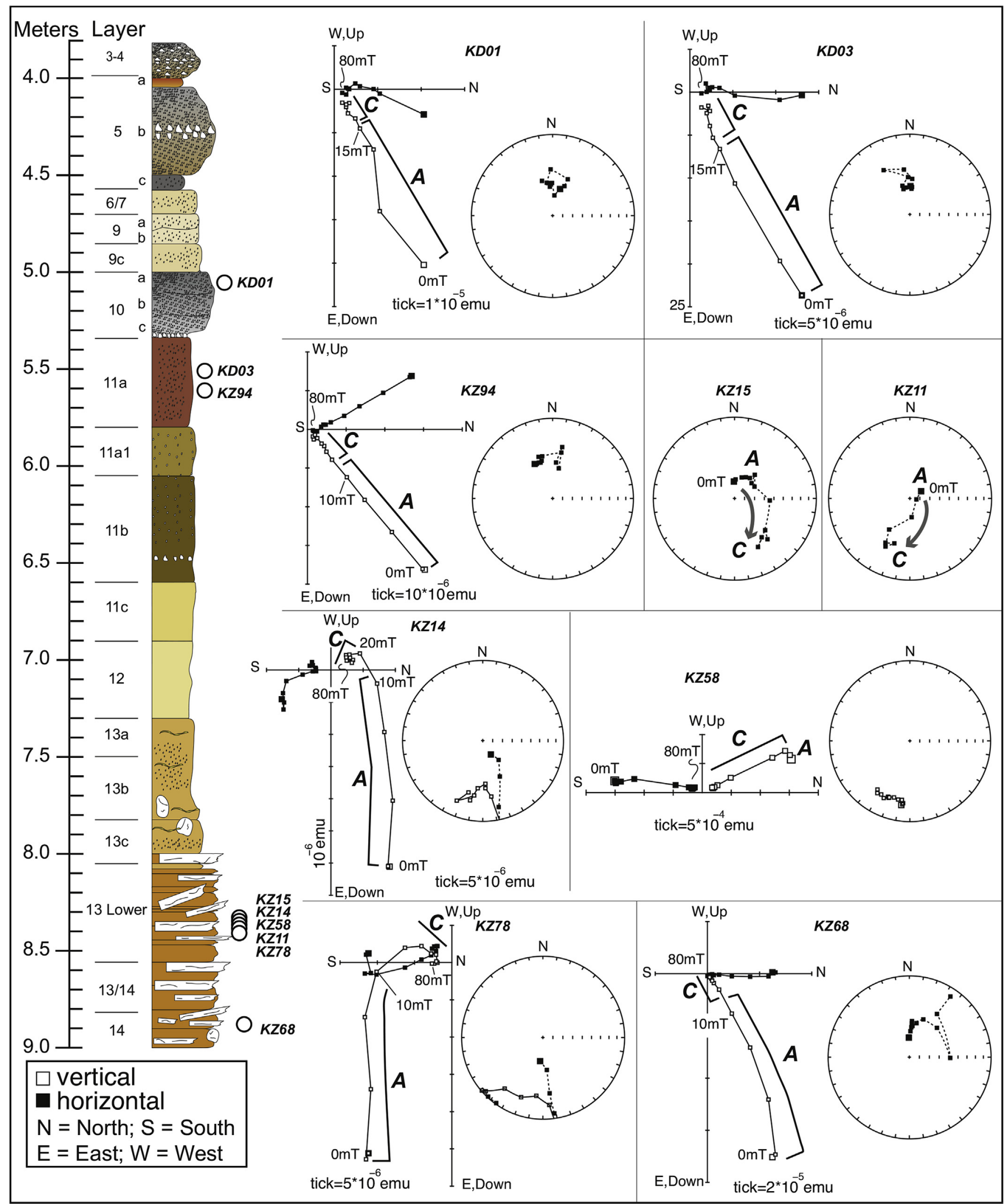

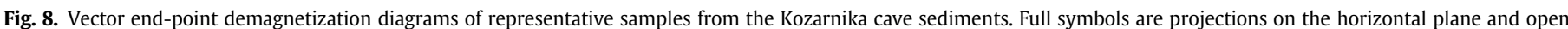
symbols on the vertical plane. Demagnetization temperatures are expressed in ${ }^{\circ} \mathrm{C}$. 


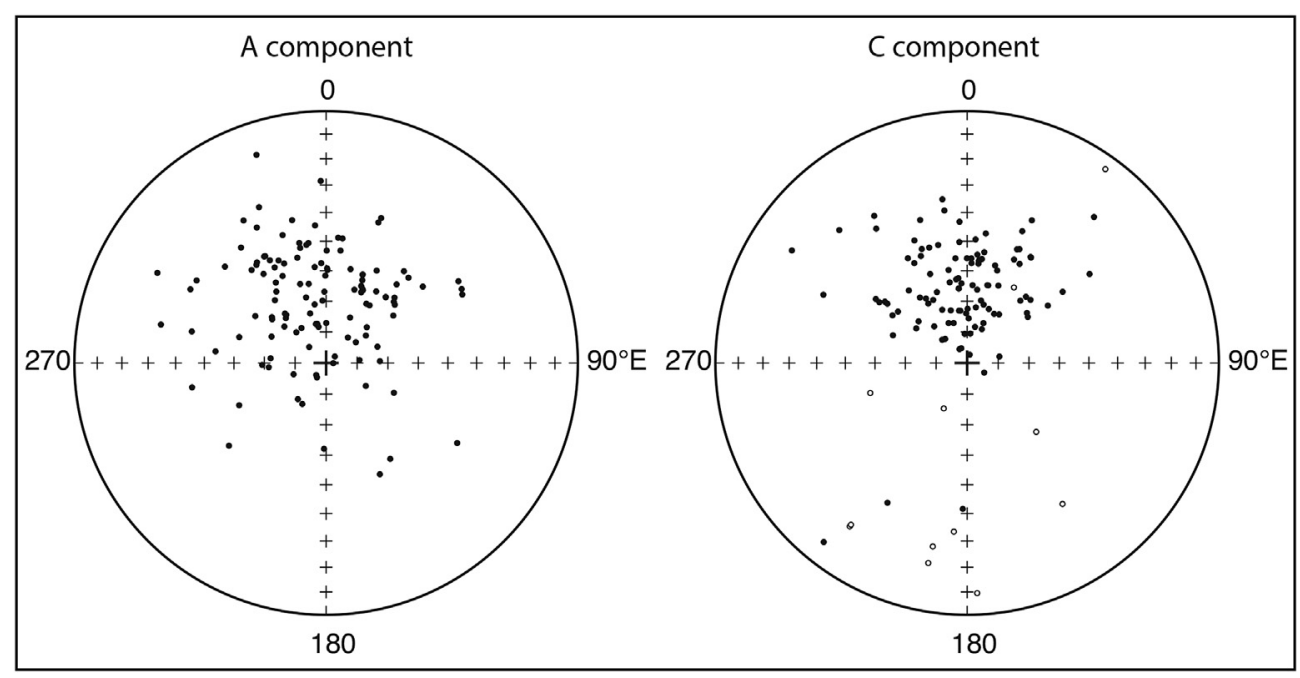

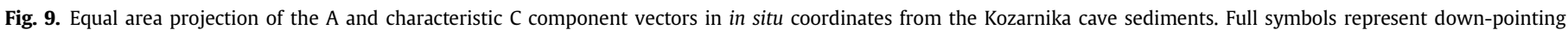
vectors, open symbols represent up-pointing vectors.

scattered, generally northerly declinations (Figs. 8 and 9). At higher AF demagnetization steps, the NRM becomes harder to release; a characteristic remanent magnetization component, termed $\mathrm{C}$, was isolated in 119 samples, up to a maximum AF field of $80 \mathrm{mT}$ (Fig. 8). These $C$ components are either oriented northerly and down, and hence they constitute a sort of a prosecution at higher AF values of the A components, or show a tendency to turn to southerly declinations and upward (negative) inclinations (Figs. 8 and 9). The bipolar C components, with mean angular deviation (MAD) values of usually less than $10^{\circ}$ (Fig. 5C), are grouped along an axis with a mean (northerly) declination $=358.3^{\circ} \mathrm{E}$ and inclination $=62.5^{\circ}$ ( $\mathrm{n}=119, \mathrm{k}=9.8, \alpha_{95}=4.4^{\circ}$; Fig. 9).

Both the A and C components of the NRM are released in AF field intensities that reside well within the IRM acquisition spectrum of the soft coercivity magnetite phase (Figs. 6 and 7). The (subsidiary) hard coercivity phase (hematite and/or goethite), which shows up only in the IRM acquisition experiments and in fields above $100 \mathrm{mT}$, does not seem to carry any sizable portion of the NRM, which is virtually completely unblocked by $80 \mathrm{mT}$. This suggests that the $C$ components and the normal and reverse magnetic polarities that they define are carried by the same ferromagnetic (magnetite) phase, irrespective of polarity, which supports the primary nature of these magnetic components.

The declination and inclination values of the $C$ components were used to calculate virtual geomagnetic pole (VGP) latitudes and plotted versus stratigraphic depth (Fig. 5D). VGP latitudes approaching $+90^{\circ}$ are interpreted as normal polarity and VGP latitudes approaching $-90^{\circ}$ as reverse polarity, thus defining a sequence of stratigraphically superposed normal and reverse magnetozones (Fig. 5E). The section is characterized by consistent normal magnetic polarity from upper Layers $9 \mathrm{a}-\mathrm{b}$ at $4.7 \mathrm{~m}$ down to $8.3 \mathrm{~m}$ within Layer 13 Lower. This relatively thick normal polarity interval is interrupted by anomalous sample KA10 at $6.48 \mathrm{~m}$ in the lower part of Layer 11b displaying a southerly-and-up C component direction that is associated with anomalously high NRM and susceptibility values (Fig. 5D and E); this sample was also highly anisotropic during IRM experiments whereby the induced magnetization was at a high angle relative to the applied fields (Fig. 6A). Below meter level 8.3, and still within Layer 13 Lower, as well as in underlying Layer $13 / 14$, reverse polarity C component directions have been observed after removal of a pervasive initial overprint component of normal polarity. These reverse polarity $\mathrm{C}$ component directions are characterized by a relatively high degree of scattering possibly due to incomplete cleaning of the normal polarity overprint. At meter level 8.5 at the base of Layer 13 Lower, two superposed samples showed hard-coercivity component directions of exclusive normal polarity, while at the section bottom, Layer 14 is characterized again by hard-coercivity component directions of exclusive normal magnetic polarity (Fig. 5D and E).

\section{Discussion}

The Kozarnika magnetostratigraphic profile was tentatively correlated to the reference geomagnetic polarity time scale (GPTS; Lourens et al., 2004) to assess the age of the cave sediments (Fig. 10). We interpret the thick normal magnetic polarity interval extending from Layers 9a-b at $4.7 \mathrm{~m}$ down to $8.3 \mathrm{~m}$ within Layer 13 Lower (Fig. 5D and E) as a record of the Brunhes Chron ( $\leq 0.78 \mathrm{Ma})$ (Fig. 10). This interpretation agrees with two independent lines of evidence:

(i) The radiocarbon and OSL ages in the upper layers (e.g., 31.2 ka in Layer 5b; 128 ka to $183 \mathrm{ka}$ in Layer 10b) clearly indicate that the section top formed since the very end of the Middle Pleistocene and especially in the Late Pleistocene (= late Brunhes) (Fig. 10).

(ii) As previously stated, the presence in most of the analyzed samples of a narrow grain size distribution in the silt range indicates loess as a dominant textural component in the Kozarnika sedimentary infill down at least to Layers $13 a-c$ (layers below are alluvial in origin). The Kozarnika cave is located at the south-western margin of the Bulgarian lower Danube loess belt (Haase et al., 2007; Buggle et al., 2009, 2013) where loess deposition generally started sometime between the Jaramillo Subchron (0.99 Ma) and the Brunhes-Matuyama boundary (0.78 Ma) (Sartori et al., 1999; Jordanova et al., 2008; Fitzsimmons et al., 2012; Marković et al., 2012, 2015; Muttoni et al., 2015). This age window (0.78-0.99 Ma) thus represents a maximum likely age of onset of loess accumulation in the Kozarnika cave, implying that the lowermost cave loess of Layers $13 a-c$ should not be older than $0.99 \mathrm{Ma}$, in agreement with our magnetostratigraphic interpretation indicating that these layers are younger than $0.78 \mathrm{Ma}$ (Fig. 10; see also below). 


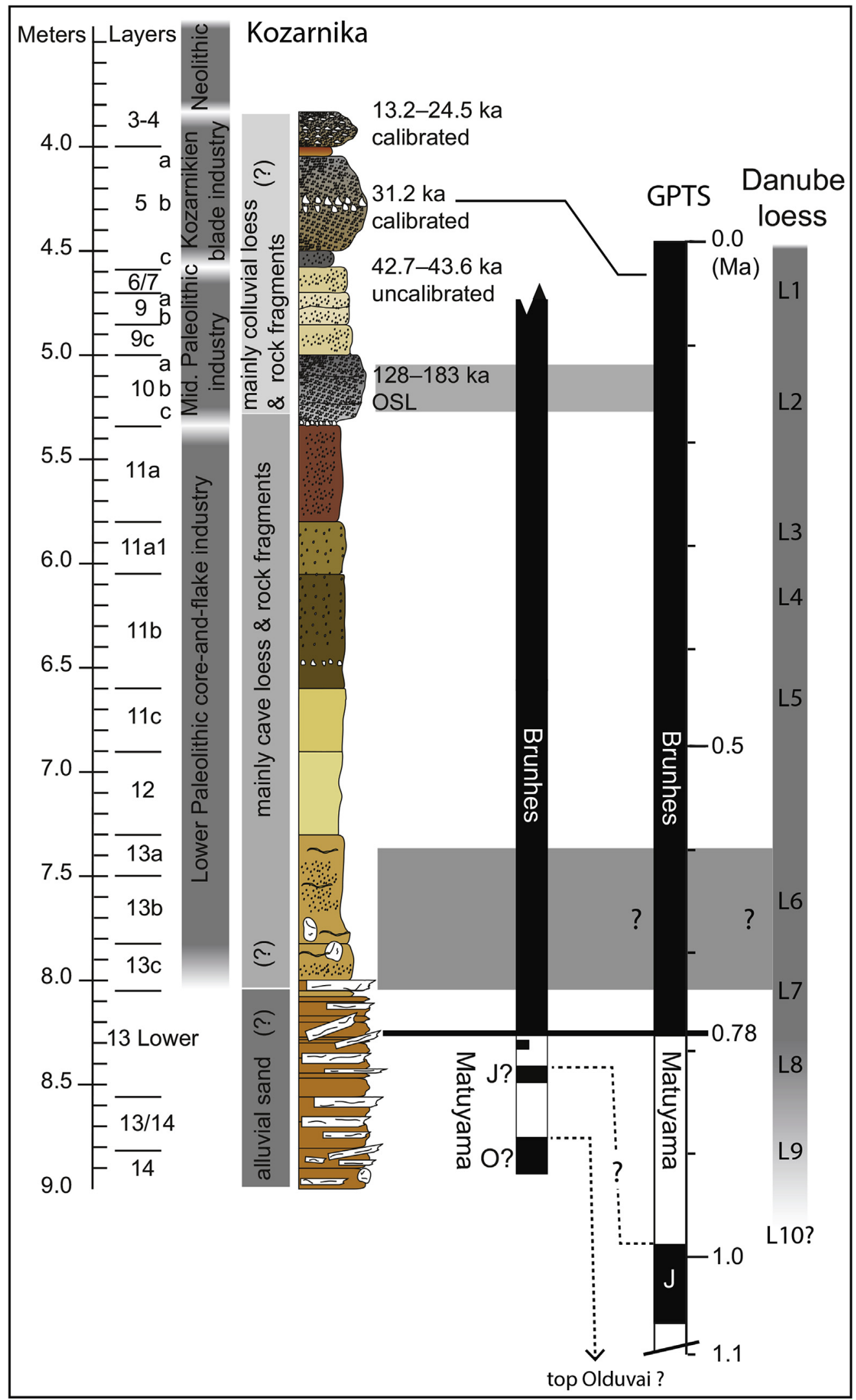

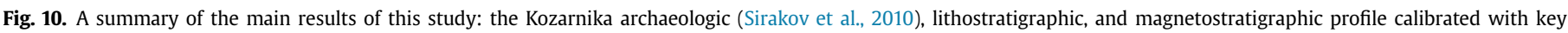

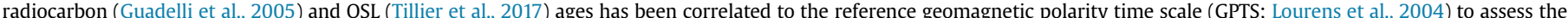

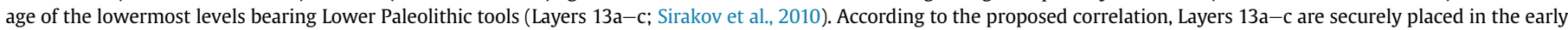

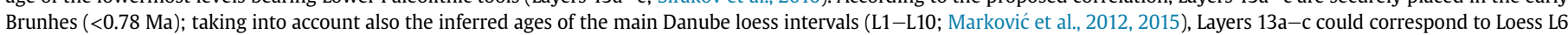
to $\mathrm{L} 7$ in the $\sim 0.6$ to $\sim 0.75 \mathrm{Ma}$ time interval. 
According to the above, we regard our placement of the Brunhes-Matuyama boundary at $\sim 8.3 \mathrm{~m}$ within the mid part of Layer 13 Lower as robust (Fig. 10). The lowermost levels with Lower Paleolithic tools are in Layers $13 a-c$, which therefore appear to lie in the early Brunhes close in age to the Brunhes-Matuyama boundary (Fig. 10). Assuming that Layers 13a-c correspond to Loess L6 to L7 of the Danube loess-paleosol sequence (e.g., Marković et al., 2012, 2015), a tentative age of $\sim 0.6$ to $\sim 0.75$ Ma for these lowermost tool-bearing layers can be derived (Fig. 10).

Farther downsection, the thin interval with positive inclinations centered at $8.5 \mathrm{~m}$ at the base of Layer 13 Lower (Fig. 5D and E) could be speculatively interpreted as a record of the Jaramillo subchron (0.99-1.07 Ma) (Fig. 10), whereas the lowermost thin interval with positive inclinations at $8.7 \mathrm{~m}$ in alluvial Layer 14 (Fig. 5D and E) could be a partial record of the Olduvai subchron, for which, however, we lack a record of its base (Fig. 10). While the estimated position of the Brunhes-Matuyama boundary is relatively robust in the section, the interpretation of these thin short normal polarity intervals embedded in secure reverse polarity (Matuyama) is subject to uncertainty due to the sedimentological complexity of these layers that may have experienced post-depositional clay illuviation or sediments redistribution from upper layers during the Brunhes Chron, or may have even experienced localized normal polarity overprints due to retarded lock-in of the NRM (Fig. 10).

According to previous magnetostratigraphic analyses reported in Sirakov et al. (2010), Layer 11b contains low magnetic inclination values tentatively interpreted as indicating the occurrence therein of the Brunhes-Matuyama boundary, in apparent contradiction with our findings. Based on this initial report, we paid particular attention to Layer 11b where paleomagnetic sampling resolution was particularly high. We found one sample at $6.48 \mathrm{~m}$ in the lower part of Layer 11b displaying upward and southerly directions; however, the sample magnetic properties were unusual, associated with high NRM values and a highly anisotropic response to IRM experiments. Moreover, there is no evidence in this densely sampled interval of a clear and persistent normal-to-reverse polarity reversal (Fig. 5D and E). Considering all the data, we are confident in the placement of the Brunhes-Matuyama boundary (0.78 Ma) at $~ 8.3 \mathrm{~m}$ within Layer 13 Lower (Fig. 5D and E).

As stressed in the Introduction, stratigraphic gaps may be present in cave entrance settings like Kozarnika (Farrand, 2001); for example, there is evidence within Layer 11a of burrowing with associated erosion of sediment. However, our magnetostratigraphic data with a thick and persistent normal polarity interval (Brunhes Chron) underlain by reverse polarity (Matuyama Chron), used in conjunction with the temporally ordered sequence of lithic industries (Guadelli et al., 2005; Sirakov et al., 2010), seem to exclude the presence of major stratigraphic gaps on the order of $10^{5}$ years.

These new magnetostratigraphic data prompt the necessity to continue investigating the complex mammal associations retrieved throughout the sequence. According to Sirakov et al. (2010), the lower Layers $11 \mathrm{~b}-13$ should belong to MNQ zones 19 to 17 , which, according to a recent radiochronologic $\left({ }^{40} \mathrm{Ar} /{ }^{39} \mathrm{Ar}\right)$ reassessment of classic mammalian localities from France, should correspond to a time interval comprised between $\sim 1.2$ and $\sim 2.6 \mathrm{Ma}$ (Nomade et al., 2014). This time interval corresponds to the early Matuyama Chron and the embedded Olduvai subchron (1.78-1.94 Ma), in contradiction with our findings that place the Brunhes-Matuyama boundary ( $0.78 \mathrm{Ma})$ in Layer 13 Lower. Indeed, alluvial Layer 14 at the very base of the sequence, below Layer 13 Lower, could contain a record of the Olduvai, but the taphonomic analysis of the fauna in Layers 12 and $13 a-c$, and the fact that Layer 14 is entirely sterile seem to preclude that certain mammal bone fragments attributed by Sirakov et al. (2010) to MNQ 19-17 could have been reworked at the base of Layer 13. Indeed, the disagreement between mammal biostratigraphy and magnetostratigraphy will need further investigation.

\section{Conclusions}

We presented a complete magnetostratigraphic profile of the Kozarnika cave sediments that constrains the age of the lowermost levels with Lower Paleolithic tools (Layers 13a-c) to the early Brunhes at nominal ages of $\sim 0.6$ to $\sim 0.75$ Ma (Fig. 10). Our data represent a conspicuous revision of previous estimates based on mammal biostratigraphy of hominin presence at Kozarnika as early as 1.4-1.6 Ma (Sirakov et al., 2010; see also Michel et al., 2017). This age revision brings Kozarnika into better agreement with a recent critical reviews indicating that the earliest main peopling of Europe occurred in a chronological window comprised between the top of the Jaramillo subchron (0.99 Ma) and the Brunhes-Matuyama boundary (0.78 Ma) (Muttoni et al., 2017; see also Muttoni et al., 2014). Although Kozarnika seems to have been first occupied at later times, the pre-Brunhes but post-Jaramillo time interval represents a prime target for surveys in search of additional sites in the Danube area with mammal immigrants from Asia and Africa (e.g., Kostolac, Serbia; Muttoni et al., 2015) possibly including early hominins.

\section{Acknowledgements}

Aleta Guadelli is warmly thanked for assistance in the field. Agostino Rizzi is thanked for helping with SEM-EDS analysis. G.M. and E.M. were supported by grant from Fondo Scavi Archeologici Università degli Studi di Milano 2015. This is Lamont-Doherty contribution \#8159.

\section{References}

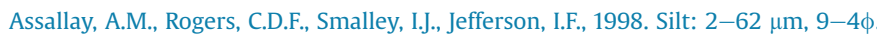
Earth Sci. Rev. 45, 61-88.

Buggle, B., Hambach, U., Glaser, B., Gerasimenko, N., Marković, S.B., Glaser, I., Zöller, L., 2009. Magnetic susceptibility stratigraphy and spatial and temporal palaeoclimatic trends in East European loess paleosol sequences. Quat. Int. 196, 86-106.

Buggle, B., Hambach, U., Kehl, M., Marković, S.B., Zöller, L., Glaser, B., 2013. The progressive evolution of a continental climate in SE-Central European lowlands during the Middle Pleistocene recorded in loess paleosol sequences. Geology 41, $771-774$.

Castiglioni, G.B., Cremaschi, M., Guerreschi, A., Meneghel, M., Sauro, U., Van Vliet, L.B., 1990. The loess deposits in the Lessini plateau. In: Cremaschi, M. (Ed.), The Loess in Northern and Central Italy: a Loess Basin between the Alps and the Mediterranean Region. CNR, Milano, pp. 41-59.

Coudé-Gaussen, G., 1990. The loess and loess-like deposits along the sides of the western Mediterranean Sea: genetic and palaeoclimatic significance. Quat. Int. $5,1-8$.

Cremaschi, M., 1987. Loess deposits of the plain of the Po and the adjoining Adriatic basin (Northern Italy). In: Pecsi, M., French, H.M. (Eds.), Loess and Periglacial Phenomena. Akademiai Kiado, Budapest.

Dunlop, D.J., Özdemir, Ö., 1997. Rock Magnetism. Fundamentals and Frontiers. Cambridge Studies in Magnetism Series. Cambridge University Press, 573 pp.

Farrand, W.R., 2001. Sediments and stratigraphy in rockshelters and caves: a personal perspective on principles and pragmatics. Geoarchaeology 16 (5), $537-557$.

Ferraris, M., Sala, B., Scola, V., 1990. The late Pleistocene fauna with Pliomys lenki from the Ghiacciaia cave loess (Northern Italy). Quat. Int. 5, 71-79.

Ferrier, C., Leblanc, J.-Cl, Berthet, A.-L., Delfour, G., 2009. La grotte Kozarnika (Gara Oreshets, Bulgarie): données stratigraphiques, géologiques et sédimentologiques. In: Gatsov, I., Guadelli, J.-L. (Eds.), Saxa Loquuntur! “The Stone Will Speak!", pp. 13-27. Avalon, Sofia.

Fitzsimmons, K., Marković, S., Hambach, U., 2012. Pleistocene environmental dynamics recorded in the loess of the middle and lower Danube basin. Quat. Sci. Rev. 41, 104-118.

Gale, S.J., Hoare, P.G., 1991. Quaternary Sediments. Belhaven Press, London.

Guadelli, J.L., Sirakov, N., Ivanova, S., Sirakova, S., Anastassova, E., Courtaud, P., Dimitrova, I., Djabarska, N., Fernandez, P., Ferrier, C., Fontugne, M., Gambier, D. Guadelli, A., Iordanova, D., Iordanova, N., Kovatcheva, M., Krumov, I., Leblanc, J.C., Mallye, J.B., Marinska, M., Miteva, V., Popov, V., Spassov, R., Taneva, S., Tisterat-Laborde, N., Tsanova, T., 2005. Une séquence du 
Paléolithique inférieur au Paléolithique récent dans les Balkans: la grotte Kozarnika à Orechets (nord-ouest de la Bulgarie). In: Molines, N., Moncel, M.-H. Monnier, J.-L. (Eds.), Les Premiers Peuplements en Europe, British Archaeological Reports, International Series, vol. 1364, pp. 87-103.

Haase, D., Fink, J., Haase, G., Ruske, R., Pécsi, M., Richter, H., Altermann, M., Jäger, K.D., 2007. Loess in Europe - its spatial distribution based on a European loess map, scale 1:2,500,000. Quat. Sci. Rev. 26, 1301-1312.

Jordanova, D., Hus, J., Evlogiev, J., Geeraerts, R., 2008. Paleomagnetism of the loess/ palaeosol sequence in Viatovo (NE Bulgaria) in the Danube basin. Phys. Earth Planet. Interiors 167 (1), 71-83.

Kruiver, P.P., Dekkers, M.J., Heslop, D., 2001. Quantification of magnetic coercivity components by the analysis of acquisition curves of isothermal remanent magnetisation. Earth Planet. Sci. Lett. 189 (3), 269-276.

Krumbein, W.C., Sloss, L.L., 1963. Stratigraphy and Sedimentation. Freeman \& Co., San Francisco, USA.

Le Ribault, L., 1977. L'exoscopie des Quartz. Masson, Paris.

Lourens, L.J., Hilgen, F.J., Laskar, J., Shackleton, N.J., Wilson, D., 2004. The Neogene period. In: Gradstein, F.M., Ogg, J.G., Smith, A.G. (Eds.), A Geologic Time Scale 2004. Cambridge University Press, Cambridge, pp. 409-440.

Marković, S.B., Hambach, U., Stevens, T., Jovanović, M., O'Hara-Dhand, K., Basarin, B. Lu, H., Smalley, I., Buggle, B., Zech, M., 2012. Loess in the Vojvodina region (Northern Serbia): an essential link between European and asian Pleistocene environments. Neth. J. Geosciences 91, 173-188.

Marković, S.B., Stevens, T., Kukla, G.J., Hambach, U., Fitzsimmons, K.E., Gibbard, F. Buggle, B., Zech, M., Guo, Z., Hao, Q., Wu, H., O'Hara Dhand, H., Smalley, I.J. Újvári, G., Sümegi, P., Timar-Gabor, A., Veres, D., Sirocko, F., Vasiljević, D.A., Jary, Z., Svensson, A., Jović, V., Lehmkuhl, F., Kovács, J., Svirčev, Z., 2015. Danube loess stratigraphy - towards a pan-European loess stratigraphic model. EarthScience Rev. 148, 228-258.

Martignier, L., Adatte, T., Verrecchia, E.P., 2013. Bedrock versus superficial deposits in the Swiss Jura Mountains: what is the legitimate soil parent material? Earth Surf. Process. Landforms 38, 331-345.

Michel, V., Shen, C.C., Woodhead, J., Hu, H.M., Wu, C.C., Moullé, P.É., Khatib, S., Cauche, D., Moncel, M.H., Valensi, P., Chou, Y.M., Gallet, S., Echassoux, A. Orange, F., de Lumley, H., 2017. New dating evidence of the early presence of hominins in Southern Europe. Sci. Rep. 7, 10074.

Muttoni, G., Kent, D.V., Scardia, G., Monesi, E., 2014. Migration of hominins with megaherbivores into Europe via the Danube-Po gateway in the late Matuyama climate revolution. Riv. Ital. Paleontol. Stratigr. 120, 351-365.

Muttoni, G., Scardia, G., Dimitrijević, V., Kent, D.V., Monesi, E., Mrdjic, N., Korać, M., 2015. Age of Mammthus trogontherii from Kostolac, Serbia, and the entry of megaherbivores into Europe during late Matuyama climate revolution. Quat. Res. 84, 439-447.

Muttoni, G., Scardia, G., Kent, D.V., 2017. Early hominins in Europe: the Galerian migration hypothesis. Quat. Sci. Rev. in press.

Nomade, S., Pastre, J.F., Guillou, H., Faure, M., Guérin, C., Delson, E., Debard, E., Voinchet, P., Messager, E., 2014. 40 Ar/39 Ar constraints on some French landmark Late Pliocene to Early Pleistocene large mammalian paleofaunas: paleoenvironmental and paleoecological implications. Quat. Geochronol. 21, 2-15.

Pavelić, D., Kovačić, M., Banak, A., Jiménez-Moreno, G., Marković, F., Pikelj, K., Vranjković, A., Premužak, L., Tibljaš, D., Belak, M., 2016. Early Miocene European loess: a new record of aridity in southern Europe. Geol. Soc. Am. Bull. 128, $110-121$.

Popov, V.V., Marinska, M., 2007. An almost one million year long (Early to Late Pleistocene) small mammal succession from the archaeological layers of Kozarnika cave in Northern Bulgaria. Cour. Forschungsinstitut Senckenberg 259, 79-92.

Pye, K., 1987. Aeolian Dust and Dust Deposits. Academic press, London, 334 pp.

Pye, K., 1995. The nature, origin and accumulation of loess. Quat. Sci. Rev. 14, 653-667.

Sartori, M., Heller, F., Forster, T., Borkovec, M., Hammann, J., Vincent, E., 1999. Magnetic properties of loess grain size fractions from the section at Paks (Hungary). Phys. Earth Planet. Interiors 116, 53-64.

Sirakov, N., Guadelli, J.L., Ivanova, S., Sirakova, S., Boudadi-Maligne, M., Dimitrova, I., Ph, F., Ferrier, C. Guadelli, A., Iordanova, D., Iordanova, N., 2010. An ancient continuous human presence in the Balkans and the beginnings of human settlement in western Eurasia: a Lower Pleistocene example of the Lower Paleolithic levels in Kozarnika cave (North-western Bulgaria). Quat. Int. 223, 94-106.

Tillier, A.-M., Sirakov, N., Guadelli, A., Fernandez, P., Sirakova, S., Dimitrova, I., Ferrier, C., Krumov, I., Leblanc, J.-C., Miteva, V., Popov, V., Taneva, S., Guadelli, J.L., 2017. Evidence of Neanderthals in the Balkans: the infant radius from Kozarnika Cave, Bulgaria. J. Hum. Evol. 111, 54-62.

Zerboni, A., Trombino, L., Frigerio, C., Livio, F., Berlusconi, A., Michetti, A.M., Rodnight, H., Spötl, C., 2015. The loess-paleosol sequence at Monte Netto: a record of climate change in the Upper Pleistocene of the central Po Plain, northern Italy. J. Soils Sediments 15, 1329-1350. 